\title{
Restrictive Covenants: The Lack of an Effective Remedy in India
}

\author{
Girish Deepak*
}

\section{Abstract}

Grant of damages in case of restrictive covenants is an important issue plaguing commercial contracts in India. This paper attempts to explore the best possible practices to resolve this issue, through a detailed analysis of various Indian and Foreign case laws. Various sections of the Specific Relief Act 1963, deal with the necessary remedies to protect parties against contractual breaches such as section 38, which allows for Specific Performance and section 42 for Injunctions in the case of Negative Covenants, it curiously excludes the latter from eligibility for damages under section 40 of the Act. This has led to a scenario wherein, while breach of positive covenants ("agreement to do something or perform an obligation") are remedied through grant of damages; negative (restrictive) covenants ("agreement not to do something") have no similar remedy, leaving parties only entitled to nominal damages. The argument supporting this discrimination is that damages cannot be quantified in the case of breach of negative covenants, however, developments in the common law jurisprudence have found a unique solution. The landmark decision of the House of Lords in the Wrotham Park case, supported by

* The National University of Advanced Legal Studies, Kochi, India; girishde@gmail.com 
subsequent decisions has crystallized certain principles to be followed in this regard. It is time India also adopted these changes to adhere to International best practices, given our recent push towards foreign investment.

Keywords: Damages, Injunction, Restrictive Covenants, Specific Relief Act 1963, Wrotham Park principles.

\section{Introduction}

Since the formation of the current government constituted by the NDA in India, there has been a marked shift in the treatment meted out towards commerce and business. This shift has been part of a gradual process to promote business and capitalism in India, since the liberalization of the economy in 1991. With this rapid evolution in forms of commercial transactions and their increasing complexity, modern day businesses are frequently faced with issues of contractual breaches. These companies are forced to adopt a variety of strategies to enforce agreements or alternatively, safeguard their interests by limiting the economic losses caused by non-performance of contracts. While this is indeed a common feature, given the uncertainty of businesses and the risk factor which is inherently involved in them, it has always been the function of law to try and protect the innocent party, i.e. the one suffering the consequences of a breach.

This is surmised succinctly in the Latin maxim pacta sunt servanda, which means that parties must adhere to a specific pact (contract). ${ }^{1}$ Thus, any breach of this duty deserves appropriate punishment. This is premised on the fundamental principle that when a breach occurs, the law must intervene to guarantee that the non-defaulting party does not suffer due to the acts of the defaulting party. This is otherwise referred to as returning the parties to the quo ante position, as if the transaction never took place. $^{2}$

Under Indian contract law, while there are numerous remedies for breach of contracts, such as a claim of specific performance or the grant of injunctions; one of the fundamental remedies ultimately

${ }^{1}$ BLACK'S LAW DICTIONARY (8th ed. 2004).

$2 \S 1,66$ Am. Jur. 2d Restitution and Implied Contracts (2001). 
relied upon by parties is an action for damages ${ }^{3}$. Section 73 of the Indian Contracts Act 1872, enacted on $25^{\text {th }}$ April, 1872, governs such scenarios and prescribes that the party that has suffered from the breach must be compensated to the full extent of their losses. This provision was created with the intention of remedying the loss sustained by the innocent party by mandating that the party committing breach of a stipulation is responsible for its reparation through monetary payments. This remedy is hence often regarded as the ideal means to return parties to the status prior to their agreement in economic terms. However, this remedy is not available readily for every circumstance under Indian law, which is clearly a cause for concern, as this would leave innocent parties devoid of remedy. This paper is concerned with the specific circumstance of section 42 of the Specific Relief Act, 1963 enacted on $13^{\text {th }}$ December. The only available remedy in the context of negative covenants is an injunction.

In a broad categorization, all contractual stipulations can be classified into two types - positive covenants ("agreement to do something or perform an obligation") or negative (restrictive) covenants ("agreement not to do something"). ${ }^{4}$ Both these types of covenants are usually sought to be enforced through the special remedies provided under the Specific Relief Act, 1963 and the provisions under the Indian Contract Act 1872. One such essential provision of the Specific Relief Act is enshrined under Section 42, which provides for a much needed remedy, namely, an injunction to enforce restrictive covenants. ${ }^{5}$

From the nature of this remedy, it seems to be an action for specific performance couched in the shell of an injunction. Explained in simpler terms, when there is a positive covenant in an agreement and it is sought to be enforced, one would initiate action under Specific Performance as a remedy. However, when the agreement is for a negative (restrictive) covenant, the remedy required is an

$3 \S 73$, Indian Contracts Act, 1872, No. 9, Acts of Parliament, 1872; See also Hadley v. Baxendale, (1854)E.W.H.C. J70.

${ }^{4}$ MULLA, THE INDIAN CONTRACT ACT 244 (15 ed., Lexis Nexis Publications2015).

${ }^{5} \S$ 42,Specific Relief Act, 1963, No.47, Acts of Parliament, 1963. 
injunction, preventing the party from reneging on their contractual commitments. ${ }^{6}$

\section{Restrictive or Negative Covenants: The Remedies Available}

The primary remedy available as mentioned above is the grant of an injunction in accordance with section 42 of the Specific Relief Act 1963 . This section presently provides the only special remedy available in the case of breach of a negative covenant. On a bare perusal of the section, it is evident that this provision was intended to provide protection to negative covenants, by allowing injunction in a broader scope of cases, by excluding circumstances in which a normal injunction would be rejected under section 41. An illustration of the following is a contract in which a person agreed to sing at a theatre for a specified period and which restrained her from singing elsewhere. In this case, ${ }^{7}$ while the positive part of the contract, mandating singing in the theatre could not be enforced, the negative part, restraining the singer could very well be enforced under Section 42 of the Specific Relief Act 1963.

While construing the application of section 42 and the grant of an injunction, there are two key principles that require mentioning. The first is that restrictive covenants may take the form of a positive covenant with an implied negative covenant. This can be seen in the case of employment contracts ${ }^{8}$, where the stipulation that a person will exclusively work for a particular employer also gives rise to the equally enforceable negative covenant restraining him from working for any other employer. This is only subject to the restriction that such covenants don't fall under Restraint of

${ }^{6}$ Forest Fibers Inc. v. KK Asia Environmental Pte. Ltd. \& Ors., (2016) SGHC; See also Richard Wheeler Doherty v. James Clagston Allman, (1878) 3 App Cas 709.

${ }^{7}$ Lumley v. Wagner(1852)E.W.H.C. (Ch) J96.

${ }^{8}$ Swift Initiative Pvt. Ltd. v. Dilip Chhabria Design Pvt. Ltd., O.M.P. (I) Nos. 454 of 2015;See also S.K. Gupta v. Hyderabad Allwyn Ltd., A.I.R. 1988 Del 324. 
Trade as defined under section 27 of the Indian Contract Act $1872 .{ }^{9}$ This prohibition under the Contracts Act is aimed at preventing contracts from imposing unconscionable restrictions. An example of this would be restraining employees from pursuing alternate careers in the same industry, once they have left the company, through a clause inserted in their employment terms and conditions.

The second principle to be considered in the grant of injunctions, relates to the standard conditions enunciated under Order XXXIX of the Civil Procedure Code, 21 st March 1908, which governs the grant of injunctions in all civil cases. These conditions include the balance of convenience and the loss caused to the party ${ }^{10}$. However, in the case of restrictive covenants, once this negative construction is established and there is a breach of the stipulation, the mere circumstance of this breach affords sufficient ground for granting the injunction. The grant of such an injunction to enforce negative covenants, once breach is established, is a settled position in India and is almost invariably granted, barring certain extenuating circumstances. ${ }^{11}$

An example of the extenuating circumstances which could result in the rejection of such a claim for injunction is the use of roads belonging to another person to reach a newly constructed property. This is primarily based on the understanding that granting such an injunction would prevent the person from accessing the property itself.12 Other examples include cases of breach of non-disclosure agreement, i.e. wherein a company agrees with an entity that certain sensitive information will not be disclosed to the public13; or

9Percept D'Markr (India) Pvt. Ltd. v Zaheer Khan \& Anr., A.I.R. 2006 S.C. 3426; See also Niranjan Shankar Golikari v. Century Spg \& Mfg Co. Ltd, (1967) 2 S.C.R. 378.

${ }^{10}$ Gujarat Bottling Co. v. Coca Cola Co., A.I.R. 1995 S.C. 2372.

${ }^{11}$ Tulsi Devi \& Ors. v. Chand Bai \& Anr., 2016 (3) R.L.W. 2050; See also Vijaya Minerals Pvt. Ltd. v. Bikash Chandra Deb,A.I.R. 1996 Cal 67.

12Bracewell \& Anr. v. Appleby, [1975] 1 Ch 408.

${ }^{13}$ Diljeet Titus v. Mr. Alfred A Adebare \& Ors., 2006 (32) P.T.C. 609 Del. 
non-solicitation agreements wherein companies agree not to solicit clients from each other's respective companies. ${ }^{14}$

In the above scenarios where an injunction to enforce the negative covenant is rejected, the only possible remedy available to the party would be an action for damages as provided for, under section 40 of the Specific Relief Act 1963.In the above mentioned cases, the form of remedy, is through damages. ${ }^{15}$ However, as is evident in the wordings of the provision, India only recognizes this remedy in the case of non-grant of relief of Specific Performance, though a similar relief in the case of injunctions is well established in common law jurisprudence. This has led to a scenario wherein, while India adopted this provision itself from common law, it has deviated in this one regard and refused to incorporate this subsequent development.

This particularly applies to situations such as the breach of NonDisclosure Agreements, where once the breach has occurred, merely obtaining an injunction is not an efficacious remedy. This is premised on the datum that the damage would have already occurred and an injunction would only prevent further disclosures. Thus, under such circumstances only damages for the loss caused to the company could possibly remedy the situation.

The grant of any such damages under section 40 is guided by the principles laid down by English Courts, ${ }^{16}$ which are:

(i) Injury to the plaintiff's right is minor.

(ii) The injury is one capable of being estimated in money.

(iii) It is one which is capable of being compensated by a small money payment.

(iv) The case is one in which it would be oppressive to the defendant to grant an injunction.

${ }^{14}$ Embee Software Pvt. Ltd. v. Samir Kumar Shaw, A.I.R. 2012 Cal 141; See also Pepsi Food Ltd. \& Ors. v. Bharat Coca Cola Holdings Pvt. Ltd., 1999 (50)D.R.J. 656.

15 FLSmidth Pvt. Ltd. v M/s.Secan Invescast (India) Pvt. Ltd, (2013) 1 C.T.C. 886.

16 Morris v. Redland Bricks Ltd., (1967) 3 All E.R. 1. 
On an analysis of the above mentioned criteria, there are clearly no significant issues with establishing the first and third criteria, as it is easy to establish the injury caused and that the appropriate remedy is through compensation. The fourth criterion does not merit consideration in the case of negative covenants as the injunction is not a valid remedy, only being an interim measure. There however exist significant issues while attempting to establish the second criteria.

This problem arises on account of quantification of damages being difficult in most cases involving negative covenants, considering that these stipulations only prevent certain acts or impose restrictions. This has led to most number of cases involving breach of a negative covenant only leading to a decree of mere nominal damages, even though the actual loss caused to the Company/Innocent Party is far greater. This is exemplified in the case of Satyam Computer Services Limited v. Ladella Ravichander, where an employee was mandated under employment bond to pay reparations in excess of INR 2,50,000 in case he abruptly terminated his employment. This valuation was based on the loss caused to the company in terms of its investment in imparting skills to the employee. However, the Court assessed damages to be INR $1,00,000$, which was less than even half the contractually agreed amount, deeming the same to be adequate. ${ }^{17}$

\section{Common Law Developments}

This particular issue of mismatch in the remedies between positive and negative covenants, was taken up in a series of common law cases which began with the decision in Wrotham Park Estate Co. $v$. Parkside Homes Ltd.18 This case involved the building of houses on land owned by the defendant in breach of a restrictive covenant agreed with the plaintiff. The High Court refused to grant injunction on the grounds that it was excessive to demolish fourteen fully constructed houses merely to satisfy the covenant between the parties, and awarded damages instead.

17 Satyam Computer Services Limited v. Ladella Ravichander,(2011) S.C.C. AP 76.

18 Wrotham Park Estate Co. v. Parkside Homes Ltd., (1974)I W.L.R. 789. 
The Court assessed the damages by creating a 'hypothetical negotiation' between the parties, and contemplated the method by which such a negotiation would have proceeded. In this case Wrotham Park had the restrictive covenant, so the Court assumed itself in the position of the party and sought to determine how much it would charge for the relaxation of the covenant prior to the beginning of the construction process. Using this methodology, the Court arrived at a fair compensation of $5 \%$ of the profits of the project (amounting to $£ 2,500$ ) for relaxing the covenant.

This case gained favorable reviews from scholars, practitioners and parties alike, obtaining the title of Wrotham Park principles. These principles successfully acted both as a sanction against the party committing the breach and at the same time provided fair compensation to the aggrieved party, bringing the situation at par with other contract cases.

The Wrotham Park principle was subsequently reiterated in the case of Jaggard v. Sawyer ${ }^{19}$, wherein a dispute involved the construction of a driveway which infringed upon the property of the Plaintiff. However, as this petition was at an advanced stage of the construction and the injunction would have barred the Defendant from accessing his house, the Court of Appeals chose to grant compensation instead, relying upon the Wrotham Park method of assessing damages. ${ }^{20}$

The recent landmark decision in the case of CF Partners (UK) LLP $v$. Barclays Bank PLC21, was also based on the Wrotham Park principles, which was used as justification for damages to the tune of 10 million Euros for breach of a confidentiality covenant by Barclays. In this case Barclays acquired certain sensitive information during a proposed merger between CF Partners and Tricorona, for which they had been engaged as an intermediary. However, this merger could not be completed and Barclays subsequently used this information to acquire Tricorona, leading inevitably to a dispute regarding the validity of such acquisition. This case in its

${ }^{19}$ Jaggard v. Sawyer,(1995), 2 AllE.R. 189.

${ }^{20}$ Experience Hendrix LLC v. Purple Haze Records Ltd., (2005) E.W.H.C. 249 (Ch).

${ }^{21}$ CF Partners (UK) LLP v. Barclays Bank PLC, (2014) E.W.H.C. 3049 (Ch). 
discussion of liability crystallized the Wrotham Park principles into five factors to consider while assessing damages:

a) The nature and the extent of the rights to be bought out.

b) The time period when the hypothetical negotiation is to be treated as taking place.

c) The form of compensation most likely to have been sought by the seller and agreed by the purchaser, assuming both were acting reasonably.

d) The principal factors or "drivers" in the negotiation between the parties. This would be highly dependent on the peculiar facts of each case.

e) Whether the overall proposed consideration is within the likely parameters given ordinary commercial considerations and proportionate to the real extent of the claimant's interest in the execution of the contract. ${ }^{22}$

These decisions still permeate in English common law, as was reiterated in the case of Morris-Garner v. One Step (Support) Limited ${ }^{23}$, where in the Court of Appeal awarded significant damages to the innocent party on the basis of the Wrotham Park principles, for the breach of non-solicitation and non-competence agreed between the parties.

\section{Critical Analysis}

As is evident from these factors, the quantification of damages must be done with extreme caution, due to the differential nature of every negative covenant. Analyzing the stance taken by the Court in defining these broad principles, it is clear that they prescribe a step by step approach for Courts which begins with analyzing the nature of the rights being restricted. As mentioned above, the application of these principles being on a case to case basis, an in-depth analysis of the first factor is essential, without which any further assessment of damages would be moot.

\footnotetext{
22 Id. at 1216.

${ }^{23}$ Morris-Garner v. One Step (Support) Limited,(2016) E.W.C.A. Civ 180.
} 
The second factor is the time period of the hypothetical negotiation, which plays an equally important role in the assessment of damages. This gains even further importance in the case of a high inflation economy like India, considering that inflation could vary prices and the eventual damages by a significant factor, even if the variation in time period is merely one or two years. Generally, the time period would be the valuation of the rights at the time of the agreement, as was the case in the Wrotham Park case.

The third and fourth factors are highly fact specific, depending on the negotiations between the parties and the expectations from the contract. The 'drivers' in such cases, are a clear reference to the party's original intentions in agreeing to such a restrictive covenant. Examples of this would be scenarios such as the case of a non-disclosure where parties are driven by secrecy or nonsolicitation agreements where the motivation is to safeguard clientele.

The fifth and final factor enunciated is a safeguard against parties obtaining any benefit from a breach and to maintain the equitable nature of the remedy. This is in keeping with the principle against unjust enrichment of either party. At times, the calculation of damages under the other principles could exceed normal valuation assigned to such transactions, but this safeguard prevents judicial inflation from perpetrating injustice. The consequences of a breach thus remain restricted to merely returning parties to the position prior to the contract.

\section{Conclusion}

It is time we ended the discrimination against restrictive covenants, which has only served to leave parties entering into such agreements devoid of remedy once their injunctions are rejected. This defeats the very purpose of the protection under Contract Law in cases of breach, allowing parties to ignore pacta sunt servanda and breach agreements with impunity, knowing that the only consequence that awaits is a sanction for nominal damages. This results in parties, though innocent, being at a disadvantage once their case falls within the extenuating circumstances in which the grant of an injunction isn't warranted. Furthermore, even in cases 
where such injunctions are granted, this does not provide a sufficient remedy and once again leaves innocent parties in a detrimental position.

Having relied upon English law to develop these statutes and remedies, India's judiciary and legislature must work together to maintain vigilance as to the subsequent development of best practices worldwide as well. Keeping in mind the common law developments, which have since evolved to remedy this particular problem and also established a well-functioning method to quantify damages in circumstances which fall under section 42 of Specific Relief Act 1963, it is well past time that India adopts this method as well. 